\title{
Analysis of Financial Ratio to Predict Financial Distress in the Sub Sector of Plantation Company on Indonesia Stock Exchange Period 2010-2018
}

\author{
Rosmei Yunita Sibarani ${ }^{1}$, Nisrul Irawati ${ }^{2}$, Iskandar Muda ${ }^{2}$ \\ ${ }^{1,2}$ Master of Management Program-Postgraduate School of University of Sumatera Utara \\ Corresponding Author: Rosmei Yunita Sibarani
}

\begin{abstract}
The decline of crude palm oil commodity prices and world demand in 2014 to 2016 lead to decline the capability of plantation companies performance. This is apparent from the declining sales capacity, increase of operating expenses, and inventory expenses and the impact is declining financial performance such as net profit. If this is allowed continuously then the consequences are the plantation sub sector companies possibly can get into the financial distress condition. This research aims to predict the level of financial distress condition and to know the relationship significance using Return On Asset (ROA), Return On Equity (ROE), Current ratio (CR), Debt to Asset Ratio (DAR), Current Liabilities to Assets Ratio (CLAR) and Debt to Equity Ratio (DER). The research population was plantation sub sector companies listed in Indonesia Stock Exchange. Researcher using purposive sampling in order to obtain a sample of 10 companies. This research uses secondary data from annual financial report of plantation sub sector companies in Indonesia Stock Exchange. Data were tested using logistic regression to explain the influence between these variables. The results of this research indicate that the Return On Equity (ROE), Current ratio (CR), Debt to Asset Ratio (DAR), and Debt to Equity Ratio (DER) did not significantly influence financial distress while Return On Asset (ROA), Current Liabilities to Assets Ratio (CLAR) significantly influence financial distress.
\end{abstract}

Keywords: Return On Asset (ROA), Return On Equity (ROE), Current ratio (CR), Debt to Asset Ratio (DAR), Current Liabilities to Assets Ratio
(CLAR) dan Debt to Equity Ratio (DER) and financial distress

\section{BACKGROUND}

The oil palm plantation and processing industry is one of the dominant industries that makes a large contribution to economic growth in Indonesia, especially since Indonesia is the largest palm oil producer in the world. Oil palm is also a source of vegetable oil, at this time it has become the main and superior agricultural commodity in Indonesia, both as a source of income for millions of farmer families, the largest foreign exchange earner comes from exports of palm oil and its derivative products, providers of employment, as well as as a source of income. a trigger and spur for the growth of new economic centers, as well as a driving force for the growth and development of the palm oil-based downstream industry in Indonesia. From 2010 to early 2014, the production of palm oil, namely CPO (crude palm oil), experienced a very significant price increase. Mid 2014 to early 2016 the price of CPO began to decline continuously and from 2017 to 2019 the price of CPO decreased significantly, causing the price of FFB (fresh fruit bunches) and PKO (palm kernel oil) to also decline. The decline in commodity prices on the international market that began in recent years has had a negative impact on plantation sector companies in Indonesia, especially those listed on the Indonesia Stock Exchange. The economic slowdown in the destination 
countries for Indonesia's commodity exports on plantation commodity prices. led to lower demand, which led to pressure

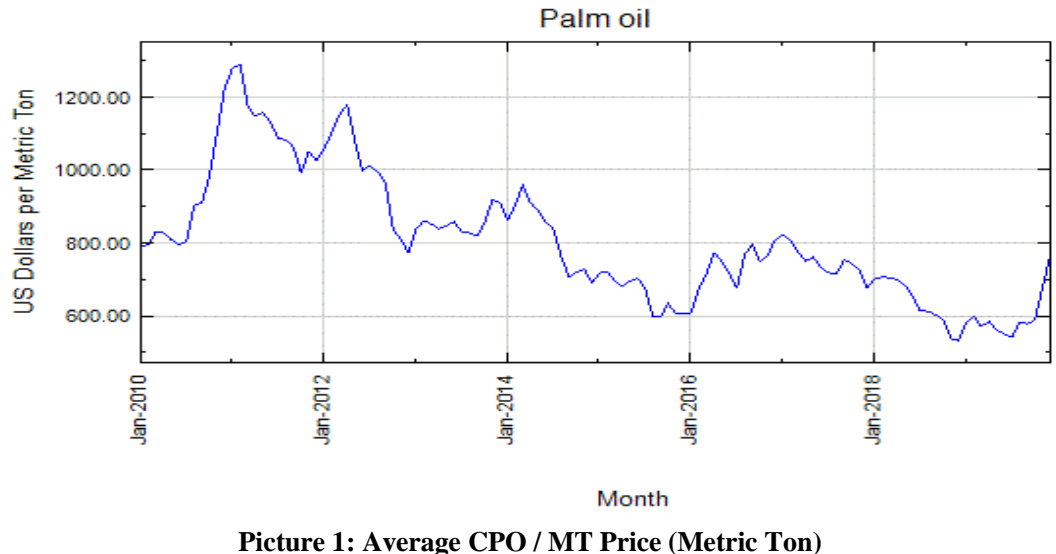

From 2014 to 2016, companies in the plantation sub-sector experienced a decrease in net profit, one of which was the increase in general expenses, selling expenses, and other expenses, which was followed by a decrease in selling prices in each product of the plantation sub-sector. The decline in the company's net profit occurred in almost all issuers listed on the Indonesia Stock Exchange (IDX). In 2017, the plantation sector was the worst performing sector on the Indonesia Stock Exchange. Much of the correction in the agricultural sector was contributed by the weaker share prices of CPO issuers. The drop in share prices of CPO issuers was due to the drop in CPO prices on the international market. This sector is still recording a $6.34 \%$ decline since the beginning of the year. Compare this with the Composite Stock Price Index (JCI) which rose $12.28 \%$ in the same period. The plantation sector is still facing challenges amid the prospect of a potential increase in the price of crude palm oil.

Regarding financial distress, there are several companies that have gone bankrupt or are threatened with bankruptcy due to financial problems. According to data obtained from https://industri.kontan.co.id, some of them, such as PT Palma Group, which is engaged in the oil palm sector, are on the edge or are threatened with bankruptcy and have suffered losses estimated at IDR 300 billion. PT Bima Agri Sawit (BAS), which recorded a loss of Rp. 13.61 billion as of June 30, 2018, its total liabilities also reached Rp. 657.09 billion, even its equity was still negative at $\mathrm{Rp}$. 120.42 billion. PT Bima Palma Nugraha (BPN), the company posted a loss for the year of $\mathrm{Rp} 50.19$ billion. Meanwhile, the total liabilities reached Rp. 868.32 billion. PT Golden Plantation Tbk, a palm oil company coded as issuer GOLL, is also experiencing financial difficulties and is even threatened with bankruptcy because two of its subsidiaries, namely PT Bumiraya Investindo (BRI) and PT Airlangga Sawit Jaya (ASJ), were declared bankrupt in 2018.

Carolina (2017) states that financial distress is defined as the stage of decline in financial conditions that occurs before bankruptcy or liquidation occurs. Financial distress can be predicted based on the company's inability or unavailability of funds to pay its maturing obligations. Financial distress (financial difficulties) of a company can be seen and measured through the ratios in the financial statements. The measure commonly used in financial statement analysis is to use financial ratio analysis. Financial distress analysis is an analysis that can help a company to anticipate the possibility that the company will experience bankruptcy caused by financial problems. 
One of the important aspects of analyzing the financial ratios of a company's financial statements is to predict the continuity or viability of the company. The financial ratios used in this study are as follows: profitability ratios, liquidity ratios, activity ratios and leverage / solvency ratios. Profitability ratios consist of Return On Asset (ROA), Return On Equity (ROE), Current ratio (CR), Debt to Asset Ratio (DAR), Current Liabilities to Assets Ratio (CLAR) and Debt to Equity Ratio (DER)

The Financial Distress event which was studied by Alifiah and Tahir (2019) at the Companies in the Manufacturing Sector in Bursa Malaysia with variables of total assets turnover ratio, current ratio, net income to total assets ratio and money supply, had a significant effect on Financial Distress. Researches on financial distress on the Stock Exchange have also been conducted in Indonesia. Rahayu and Sopian (2016) at the Food and Beverage companies on the Indonesia Stock Exchange by using financial ratios to predict financial distress. Sulistyani and Ismanto (2017) conducted research on Manufacturing Companies Listed on the IDX by using the Liquidity Ratio, Solvency Ratio, Profitability Ratio, Market Ratio variables. The research results are only the liquidity ratio, the solvency ratio which has a significant effect on financial distress. The same research was also carried out by Carolina, Elyzabet and Pratama (2017) Manufacturing Companies Listed on the IDX. The same research was also conducted by Sirait (2016) using financial ratios to predict financial distress conditions in manufacturing companies listed on the Indonesia Stock Exchange. With variable CR, QR, WCTA, TDA, NPM, ROE.

According to Sari (2016), as for the basis of using the Altman Z-score model because the Altman Z-score is one of the popular prediction models used in research on bankruptcy, the prediction produced by this model is very high at $95 \%$. This model uses the Multiple Discriminant Analysis (MDA) method. Altman's rationale uses discriminant analysis to overcome the shortcomings of multiple ratio analysis, so it is necessary to combine various ratios in order to become a meaningful prediction model. The Altman Z-score model is not only used in private companies but is also used by the Ministry of Finance to detect the performance of State-Owned Enterprises (BUMN). In this study, researchers used a model to predict manufacturing companies that have gone public, the equation is as follows:

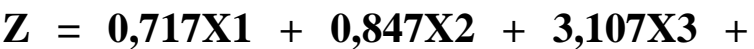 $0,420 \times 4+0,998 \times 5$}

\section{Information:}

$\mathrm{X} 1=$ Working capital to total assets (Working Capital to Total Assets).

$\mathrm{X} 2=$ Retained earnings to total assets (Retained Earnings to Total Assets).

X3 = Income before tax and interest on total assets (Earnings Before Interest and Taxes to Total Assets).

X4 = Market value of equity to book value of debt (market Value of Equity to Book Value of Total Debt).

X5 $=$ Sales to total assets (Sales to Total Assets).

The classification of performancey and non-performancey companies is based on the Z-score of the Modified Altman model, namely:

a. If the $\mathrm{Z}$ value> 2.90 is classified as a performancey company.

b. If the $\mathrm{Z}$ value $<1.23$ then it is an nonperformancey company (experiencing financial distress)

\section{Conceptual Framework}

One important aspect of analyzing the financial ratios of a company's financial statements is to predict the continuity or survival of the company. In this framework, it can explain how the influence of variable Return On Asset (ROA), Return On Equity (ROE), Current ratio (CR), Debt to Asset Ratio (DAR), Current Liabilities to Assets Ratio (CLAR) and Debt to Equity Ratio 
(DER) on the financial distress condition of plantation sub-sector companies listed on

the Indonesia Stock Exchange.

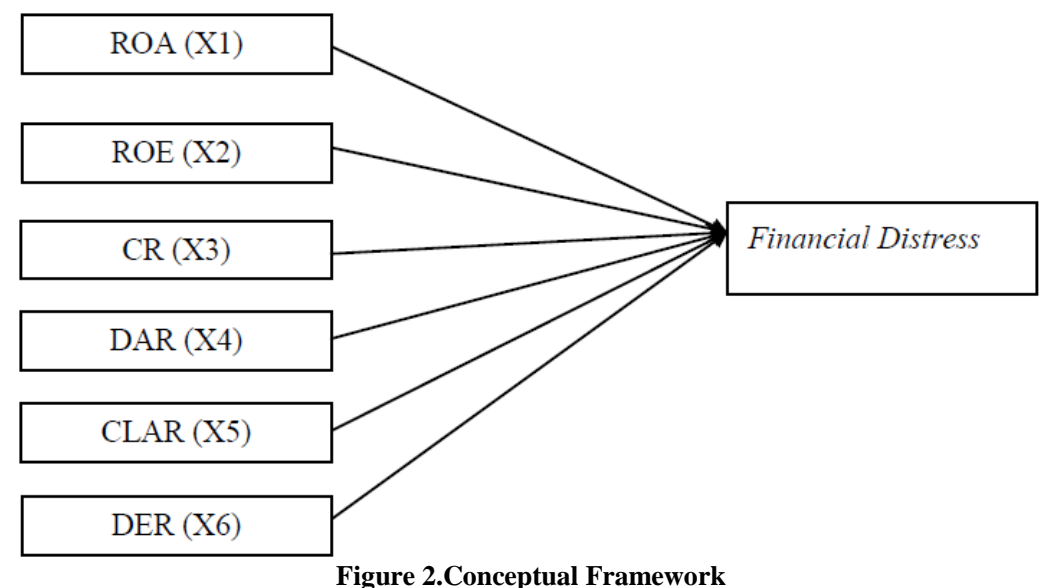

\section{Hypothesis}

H1: Return on assets (ROA) has a positive and significant effect on financial distress $\mathrm{H} 2$ : Return On Equity (ROE) has a positive and significant effect on Financial Distress H3: Current ratio (CR) has a positive and significant effect on Financial Distress

H4: Debt to Asset Ratio (DAR) has a positive and significant effect on Financial Distress

H5: Current Liabilities to Assets Ratio (CLAR) has a positive and significant effect on Financial Distress

H6: Debt to Equity Ratio (DER) has a positive and significant effect on Financial Distress

\section{RESEARCH METHODS}

This type of research is quantitative research. This study aims to obtain evidence of a causal relationship (causal relationship) between the independent variable and the dependent variable by using secondary data in the form of financial statements of oil palm plantation companies listed on the Indonesia Stock Exchange (IDX). Sources of data used in this study use secondary data, namely in the form of annual financial statements of oil palm plantation companies listed on the IDX with the end of the financial year on December 31, 2010 to December 31, 2018. Data sources can be obtained from www.idx.co.id and www.ticmi.co.id. This research was conducted on the Indonesia Stock Exchange through the website www.idx.co.id. The research period was started from June 2020 to August 2020. To analyze the research problems, the population that was the object of this study were all oil palm plantation companies listed on the IDX from 2010 to 2018, totaling 18 oil palm plantation companies. The sample selection is determined by purposive sampling in order to obtain a representative sample according to the specified criteria. The criteria for being selected as a sample are:

1. Oil palm plantation companies listed on the IDX.

2. Oil palm plantation companies that provide financial report data during the study period (2010 to 2018).

3. Plantation sub-sector companies that are not included in the relisting and delisting companies in 2010-2018

Based on these criteria, the number of oil palm plantation companies listed on the IDX and consistently existing during the study period (2010 to 2018) were 18 companies. There are 8 oil palm plantation companies that did not provide financial report data during the study period (2010 to 2018). So that the number of samples in this study were obtained as many as 10 oil palm plantation companies. 
Rosmei Yunita Sibarani et.al. Analysis of financial ratio to predict financial distress in the sub sector of Plantation Company on Indonesia Stock Exchange Period 2010-2018.

Table 1: Research Samples

\begin{tabular}{|l|l|l|l|l|}
\hline No & Code & Issuer & Sub sector & IPO date \\
\hline 1 & AALI & Astra Agro Lestari Tbk & Perkebunan & 09 December 1997 \\
\hline 2 & ANJT & Austindo Nusantara Jaya Tbk & Perkebunan & 08 May 2010 \\
\hline 3 & BWPT & Eagle High Plantation Tbk & Perkebunan & 27 October 2009 \\
\hline 4 & GZCO & Gozco Plantation Tbk & Perkebunan & 15 May 2008 \\
\hline 5 & LSIP & PP London Sumatera Indonesia Tbk & Perkebunan & 05 July 1996 \\
\hline 6 & SGRO & Sampoerna Agro Tbk & Perkebunan & 18 June 2007 \\
\hline 7 & SIMP & Salim Ivomas Pratama Tbk & Perkebunan & 09 June 2009 \\
\hline 8 & SMAR & Smart Tbk & Perkebunan & 20 November 1992 \\
\hline 9 & TBLA & Tunas Baru Lampung Tbk & Perkebunan & 14 February 2000 \\
\hline 10 & UNSP & Bakrie Sumatera Plantation Tbk & Perkebunan & 06 March 1990 \\
\hline
\end{tabular}

The data analysis method used in this research is logit regression (logistic) with the help of Eviews software. Data analysis was performed by assessing the entire model. In addition, multicollinearity testing was also carried out to determine whether the regression model found a correlation between the independent variables or the independent variables. While the testing of the hypothesis is done using:

1. Likelihood function - 2log-likelihood (Overall Model Test)

2. Hosmer and Lemeshows Goodness of fit test (Model Fit Test)

3. Nagelkerke $\mathrm{R}$ Square (Determination Coefficient Test)

4. Wald Test (Partial Effect Significance Test)

5. Omnibust Test of Model Coefficient (Simultaneous Testing)

\section{RESULTS AND DISCUSSION} Descriptive Statistical Analysis

Descriptive analysis is used to assess the characteristics or descriptions of data seen from the minimum, maximum, average, and standard deviation values based on financial distress, ROA, ROE, CR, DAR, CLAR and DER variables. Based on the descriptive statistical analysis, the sample description is as follows.

Table 2: Descriptive Statistics Based on Variables

FD, ROA, ROE, CR, DAR, CLAR and DER

\begin{tabular}{|l|l|l|l|l|}
\hline Variable & Min & Max & Mean & Std. Deviation \\
\hline FD & 0 & 1 & 0,6111 & 0,4902 \\
\hline ROA & $-0,4360$ & 0,2510 & 0,0434 & 0,0894 \\
\hline ROE & $-1,3520$ & 3,3790 & 0,1116 & 0,4266 \\
\hline CR & 0,0990 & 5,2090 & 1,3387 & 0,9371 \\
\hline DAR & 0,0820 & 1,1070 & 0,4795 & 0,2080 \\
\hline CLAR & 0,0410 & 0,9800 & 0,2140 & 0,1587 \\
\hline DER & $-30,6390$ & 11,2740 & 0,7186 & 3,7838 \\
\hline
\end{tabular}

Based on these financial ratios, the Altman analysis with a strict Z-score is used to categorize the companies into the performance and non-performance categories.

Table 3: Altman analysis with Z-score

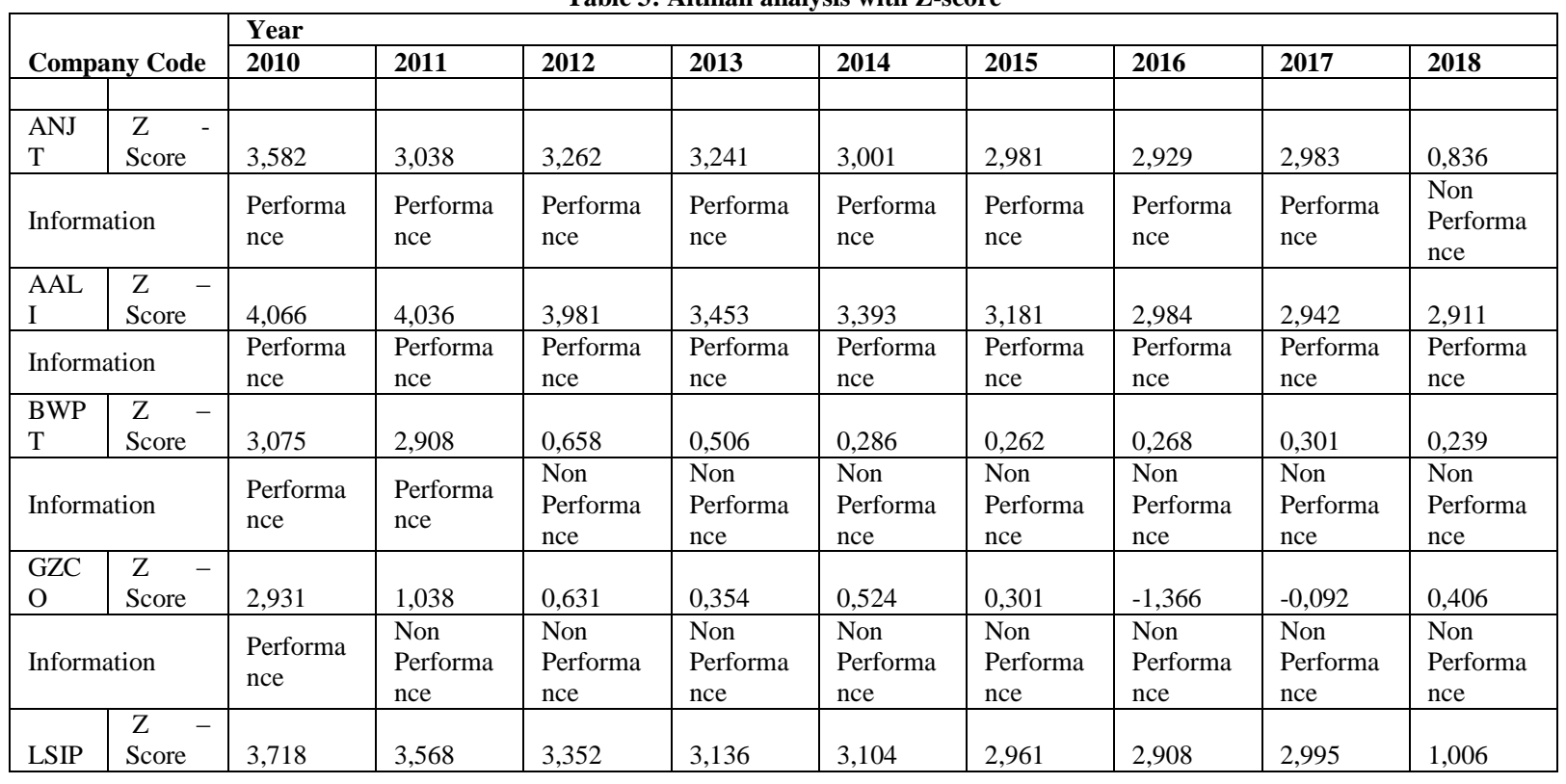


Rosmei Yunita Sibarani et.al. Analysis of financial ratio to predict financial distress in the sub sector of Plantation Company on Indonesia Stock Exchange Period 2010-2018.

\begin{tabular}{|c|c|c|c|c|c|c|c|c|c|c|}
\hline \multicolumn{2}{|c|}{ Information } & $\begin{array}{l}\text { Performa } \\
\text { nce }\end{array}$ & $\begin{array}{l}\text { Performa } \\
\text { nce }\end{array}$ & $\begin{array}{l}\text { Performa } \\
\text { nce }\end{array}$ & $\begin{array}{l}\text { Performa } \\
\text { nce }\end{array}$ & $\begin{array}{l}\text { Performa } \\
\text { nce }\end{array}$ & $\begin{array}{l}\text { Performa } \\
\text { nce }\end{array}$ & $\begin{array}{l}\text { Performa } \\
\text { nce }\end{array}$ & $\begin{array}{l}\text { Performa } \\
\text { nce }\end{array}$ & $\begin{array}{l}\text { Non } \\
\text { Performa } \\
\text { nce }\end{array}$ \\
\hline $\begin{array}{l}\text { SGR } \\
\mathrm{O} \\
\end{array}$ & $\begin{array}{l}Z^{-} \\
\text {Score }\end{array}$ & 3,147 & 3,190 & 3,013 & 2,991 & 2,905 & 1,074 & 1,151 & 2,908 & 1,091 \\
\hline \multicolumn{2}{|c|}{ Information } & $\begin{array}{l}\text { Performa } \\
\text { nce }\end{array}$ & $\begin{array}{l}\text { Performa } \\
\text { nce }\end{array}$ & $\begin{array}{l}\text { Performa } \\
\text { nce }\end{array}$ & $\begin{array}{l}\text { Performa } \\
\text { nce }\end{array}$ & $\begin{array}{l}\text { Performa } \\
\text { nce }\end{array}$ & $\begin{array}{l}\text { Non } \\
\text { Performa } \\
\text { nce }\end{array}$ & $\begin{array}{l}\text { Non } \\
\text { Performa } \\
\text { nce }\end{array}$ & $\begin{array}{l}\text { Performa } \\
\text { nce }\end{array}$ & $\begin{array}{l}\text { Non } \\
\text { Performa } \\
\text { nce }\end{array}$ \\
\hline $\begin{array}{l}\text { SIM } \\
\mathrm{P} \\
\end{array}$ & $\begin{array}{l}Z^{-} \\
\text {Score }\end{array}$ & 3,1225 & 3,0285 & 3,0919 & 2,9593 & 2,9126 & 1,1921 & 1,1341 & 2,9120 & 1,0492 \\
\hline \multicolumn{2}{|c|}{ Information } & $\begin{array}{l}\text { Performa } \\
\text { nce }\end{array}$ & $\begin{array}{l}\text { Performa } \\
\text { nce }\end{array}$ & $\begin{array}{l}\text { Performa } \\
\text { nce }\end{array}$ & $\begin{array}{l}\text { Performa } \\
\text { nce }\end{array}$ & $\begin{array}{l}\text { Performa } \\
\text { nce }\end{array}$ & $\begin{array}{l}\text { Non } \\
\text { Performa } \\
\text { nce }\end{array}$ & $\begin{array}{l}\text { Non } \\
\text { Performa } \\
\text { nce }\end{array}$ & $\begin{array}{l}\text { Performa } \\
\text { nce }\end{array}$ & $\begin{array}{l}\text { Non } \\
\text { Performa } \\
\text { nce }\end{array}$ \\
\hline $\begin{array}{l}\text { SMA } \\
\mathrm{R} \\
\end{array}$ & $\begin{array}{l}Z- \\
\text { Score }\end{array}$ & 3,527 & 4,095 & 3,476 & 3,003 & 2,985 & 2,955 & 2,960 & 3,067 & 2,938 \\
\hline \multicolumn{2}{|c|}{ Information } & $\begin{array}{l}\text { Performa } \\
\text { nce }\end{array}$ & $\begin{array}{l}\text { Performa } \\
\text { nce }\end{array}$ & $\begin{array}{l}\text { Performa } \\
\text { nce }\end{array}$ & $\begin{array}{l}\text { Performa } \\
\text { nce }\end{array}$ & $\begin{array}{l}\text { Performa } \\
\text { nce }\end{array}$ & $\begin{array}{l}\text { Performa } \\
\text { nce }\end{array}$ & $\begin{array}{l}\text { Performa } \\
\text { nce }\end{array}$ & $\begin{array}{l}\text { Performa } \\
\text { nce }\end{array}$ & $\begin{array}{l}\text { Performa } \\
\text { nce }\end{array}$ \\
\hline $\begin{array}{l}\text { TBL } \\
\mathrm{A} \\
\end{array}$ & $\begin{array}{l}Z^{-} \\
\text {Score }\end{array}$ & 0,923 & 2,913 & 2,961 & 2,977 & 2,968 & 1,170 & 1,095 & 2,944 & 2,903 \\
\hline \multicolumn{2}{|c|}{ Information } & $\begin{array}{l}\text { Non } \\
\text { Performa } \\
\text { nce }\end{array}$ & $\begin{array}{l}\text { Performa } \\
\text { nce }\end{array}$ & $\begin{array}{l}\text { Performa } \\
\text { nce }\end{array}$ & $\begin{array}{l}\text { Performa } \\
\text { nce }\end{array}$ & $\begin{array}{l}\text { Performa } \\
\text { nce }\end{array}$ & $\begin{array}{l}\text { Non } \\
\text { Performa } \\
\text { nce }\end{array}$ & $\begin{array}{l}\text { Non } \\
\text { Performa } \\
\text { nce }\end{array}$ & $\begin{array}{l}\text { Performa } \\
\text { nce }\end{array}$ & $\begin{array}{l}\text { Performa } \\
\text { nce }\end{array}$ \\
\hline $\begin{array}{l}\text { UNS } \\
\mathrm{P} \\
\end{array}$ & $\begin{array}{l}Z- \\
\text { Score }\end{array}$ & 0,157 & 0,516 & 0,320 & 0,084 & 0,104 & $-0,093$ & $-0,286$ & $-0,347$ & $-0,394$ \\
\hline \multicolumn{2}{|c|}{ Information } & $\begin{array}{l}\text { Non } \\
\text { Performa } \\
\text { nce }\end{array}$ & $\begin{array}{l}\text { Non } \\
\text { Performa } \\
\text { nce }\end{array}$ & $\begin{array}{l}\text { Non } \\
\text { Performa } \\
\text { nce }\end{array}$ & $\begin{array}{l}\text { Non } \\
\text { Performa } \\
\text { nce }\end{array}$ & $\begin{array}{l}\text { Non } \\
\text { Performa } \\
\text { nce }\end{array}$ & $\begin{array}{l}\text { Non } \\
\text { Performa } \\
\text { nce }\end{array}$ & $\begin{array}{l}\text { Non } \\
\text { Performa } \\
\text { nce }\end{array}$ & $\begin{array}{l}\text { Non } \\
\text { Performa } \\
\text { nce }\end{array}$ & $\begin{array}{l}\text { Non } \\
\text { Performa } \\
\text { nce }\end{array}$ \\
\hline
\end{tabular}

\section{Multicollinearity Test}

From the results of statistical processing above, it is known that the VIF value of all independent variables is VIF $<10$, it can be concluded that the data from this study are free from multicollinearity problems or multicollinearity does not occur.

\section{Logistic Regression}

Table 4:Logistic Regression

\begin{tabular}{|l|l|l|l|l|}
\hline Variable & Coefficient & $\begin{array}{l}\text { Std. } \\
\text { Error }\end{array}$ & z-Statistic & Prob. \\
\hline X1 & 61.48387 & 21.19987 & 2.900200 & 0.0037 \\
\hline X2 & -5.851034 & 6.890763 & -0.849113 & 0.3958 \\
\hline X3 & -0.228519 & 0.610713 & -0.374184 & 0.7083 \\
\hline X4 & -10.61449 & 5.718730 & -1.856092 & 0.0634 \\
\hline X5 & 17.65918 & 6.192603 & 2.851657 & 0.0043 \\
\hline X6 & -0.549517 & 0.641125 & -0.857114 & 0.3914 \\
\hline C & 1.503531 & 2.524891 & 0.595483 & 0.5515 \\
\hline
\end{tabular}

A constant of 1.50 means that if the six independent variables are ignored, the company is categorized as experiencing increased financial distress. The regression coefficient value of ROA is 61.48 , which is positive. This means that as the Return on Assets ratio increases, it will increase financial distress in the company. The regression coefficient value of ROE is -5.85 , which is negative. This means that as the Return on Equity ratio increases, it will reduce the level of financial distress experienced by the company. The regression coefficient value of $\mathrm{CR}$ is -0.22 , which is negative. This means that as the current ratio increases, it will reduce the level of financial distress experienced by the company.

The regression coefficient value of DAR is -10.61 , which is negative. This means that as the ratio of Debt to Asset Ratio increases, it will reduce the level of financial distress experienced by the company. The regression coefficient value of CLAR is 17.65 , which is positive. This means that as the Current Liabilities to Assets Ratio increases, it will increase financial distress in the company. The regression coefficient value of DER is -0.54 , which is negative. This means that as the Current Liabilities to Assets Ratio increases, it will reduce the level of financial distress experienced by the company.

\section{Hypothesis test}

\section{2log-likelihood (Overall Model Test)}

\begin{tabular}{|c|c|c|c|}
\hline $\begin{array}{l}\text { Hannan-Quinn } \\
\text { criter. }\end{array}$ & 0.802455 & Deviance & 51.16450 \\
\hline Restr. deviance & 120.2847 & $\begin{array}{ll}\text { Restr. } & \text { Log } \\
\text { likelihood } & \end{array}$ & -60.14236 \\
\hline
\end{tabular}


A decrease in the value between the initial -2LL (initial-2LL function) and the $2 \mathrm{LL}$ value in the next step (final -2LL) indicates that the hypothesized model is fit with the data (Ghozali, 2013). Decreasing the value of $-2 \log$ likelihood indicates that this research model is declared fit, meaning that the addition of independent variables, namely ROA, ROE, CR, DAR, CLAR, DER into the logical model will improve the fit model in this study (fit or feasible model).

\section{Hosmer and Lemeshow Goodness of fit test (Model Fit Test)}

Table 6.Hosmer and Lemeshow Test Goodness-of-Fit Evaluation for Binary Specification Andrews and Hosmer-Lemeshow Tests \begin{tabular}{l|l|l}
\hline H-L Statistic & 3.1120 & Prob. Chi-Sig(8)
\end{tabular}

Based on Table 6, it is known that the Sig. or probability 0.9271 . Note that because the probability value, which is 0.9271, is greater than the significance level, namely 0.05 , the overall model has met the model's eligibility requirements.

\section{McFadden R-squared (Test of the Coefficient of Determination)}

Table 7.McFadded R-Squared

\begin{tabular}{|l|l|l|l|}
\hline McFadden $R$-squared & $\mathbf{0 . 5 7 4 6 3 8}$ Mean dependent var & $\mathbf{0 . 6 1 1 1 1 1}$ \\
\hline
\end{tabular} \begin{tabular}{|l|l|l|l|}
\hline S.D. dependent var & 0.490229 & S.E. of regression & 0.313987 \\
\hline
\end{tabular}

Based on Table 7, the McFadden RSquared statistical value is 0.5746 . This value is interpreted as the ability of ROA, ROE, CR, DAR, CLAR, DER to influence financial distress of $57.46 \%$, the remaining $42.54 \%$ is explained by variables or other factors.

\section{Omnibus Test (Simultaneous Testing)}

\begin{tabular}{|l|l|l|l|}
\multicolumn{1}{c}{ Table 8.Omnibus Test } \\
\begin{tabular}{|l|l|l|l|l|}
\hline LR statistic & $\mathbf{6 9 . 1 2 0 2 3}$ & Avg. $\log$ likelihood & $\mathbf{- 0 . 2 8 4 2 4 7}$ \\
\hline Prob(LR statistic) & 0.000000 & & & \\
\hline
\end{tabular}
\end{tabular}

Based on Table 8, it is known that the Prob (LR statistic) value is 0.00000 $<0.05$ significance level, it is concluded that ROA, ROE, CR, DAR, CLAR, DER together or simultaneously have a significant effect on financial distress.

\section{Wald Test (Significance Test of Partial Effects)}

Table 9.Test of Significance of Partial Effects (Wald Test) Coefficient covariance computed using observed Hessian

\begin{tabular}{|l|l|l|}
\hline Variable & z-Statistic & Prob. \\
\hline X1 & 2.900200 & 0.0037 \\
\hline X2 & -0.849113 & 0.3958 \\
\hline X3 & -0.374184 & 0.7083 \\
\hline X4 & -1.856092 & 0.0634 \\
\hline X5 & 2.851657 & 0.0043 \\
\hline X6 & -0.857114 & 0.3914 \\
\hline C & 0.595483 & 0.5515 \\
\hline
\end{tabular}

Prob Value. from ROA is $0.0037<0.05$, then ROA has a positive and significant effect on financial distress.

The results of the research on the ROA value of plantation companies have a low and even negative value, which means that the company has not been able to manage assets effectively and efficiently to produce a net profit on sales, so a low ROA value is obtained and some show negative numbers which indicate financial difficulties that affect the company. Level of financial distress. A performance company will have a higher ROA ratio than a non-performance company. With high efficiency and productivity, it will result in the availability of profit (increased accumulated profit) as a source of settlement of company liabilities.

The regression coefficient of $\mathrm{ROE}$ is 5.85. Given the value of Prob. from ROE is $0.3958>0.05$, then ROE has a negative effect and does not have a significant effect on financial distress.

This ratio has no effect on financial distress, this is probably because the company uses its own capital or maximizes existing assets in running its business or in other words, the company does not use debt in managing the company. This ratio shows the extent to which the company manages its own capital effectively, measuring the rate of return on investment that has been made by the owner of the capital itself or the company's shareholders. This ratio allows management to focus on the amount of net profit that can be generated from the amount of capital invested by the shareholders. ROE can also be used as an 
indicator to assess the effectiveness of management in using equity financing to fund operations and grow the company.

The regression coefficient value of $C R$ is 0.22. Given the value for Prob. from CR is $0.7083>0.05$, then $C R$ has a negative effect and does not have a significant effect on financial distress.

This ratio apparently has no effect on financial distress, this is likely due to relatively low costs such as low cost of current debt or in other words, the company has a larger long-term debt so that when the company has short-term debt it does not really matter. The use of the Current Ratio is considered not to have a triggering effect on financial distress. This is likely due to relative costs such as lower debt costs. Companies with a decision to use debt in their balance sheets in general can increase their profitability, which in turn increases their share price, thereby increasing the welfare of shareholders and building greater growth potential and minimizing the potential for financial distress.

Prob Value. from DAR is $0.0634>0.05$, then DAR has no significant negative effect on financial distress.

In fact, this ratio has no effect on financial distress. This is probably because existing assets are not acquired through debt but through own capital or from investors so that DAR has no effect on financial distress. Debt to Asset Ratio (DAR) is a debt ratio used to measure how much the company's assets are financed by debt or how much the company's debt affects asset management.

The regression coefficient value of CLAR is 17.65. Prob Value. from CLAR is $0.0043<0.05$, then CLAR has a positive and significant effect on financial distress.

This ratio has an effect on financial distress. This is probably due to the fact that existing current debts are still able to be paid or paid off with maximum asset management or in other words the company has sufficient funds to meet its debt obligations. Current Liabilities to Assets Ratio shows a company's ability to pay off current debt using all of its assets.

The regression coefficient value of DER is -0.54. Given the value for Prob. from DER is 0.3914> 0.05, then DER has no significant negative effect on financial distress.

This ratio apparently has no effect on financial distress, this is probably due to the fact that debt or liability to the company is smaller than all assets and capital owned by the company, so that if an undesirable condition occurs such as bankruptcy or financial difficulties, the company can still pay off all debts or its obligations. Debt to Equity Ratio or DER is the main financial ratio and is used to assess the financial position of a company. This ratio is also a measure of the company's ability to pay off its obligations.

\section{CONCLUSION}

Based on the results of testing the hypothesis, it is known that of the 6 financial ratios used in examining the effect of financial ratios on financial distress, it turns out that there are 4 financial ratios that do not have a significant effect on financial distress, these ratios are Return On Equity (ROE), Current ratio. (CR), Debt to Asset Ratio (DAR), and Debt to Equity Ratio (DER), and there are 2 financial ratios that have a significant effect on financial distress, these ratios are Return On Asset (ROA), Current Liabilities to Assets Ratio ( CLAR). The two ratios are proven to have a contribution in predicting companies that experience financial distress and do not experience financial distress.

\section{REFERENCES}

1. Altman, E.I. 1968. "Financial Ratios, Discriminant Analysis and The Prediction of Corporate Bankruptcy". The Journal of Finance Vol. XXIII No. 4, September 1968.

2. Asyikin, Jumirin., Grahita Chandrarin., \& Harmono. 2018. Analysis Of Financial 
Performance To Predict Financial Distress In Sharia Commercial Banks In Indonesia. International Journal Of Accounting, Finance, And Economics. Vol1 ( 2): 1120.

3. Alifiah, Mohd Norfian., \& Muhammad Sohail Tahir. 2019. Macroeconomic Variables and the Prediction of Financial Distress Companies in the Manufacturing Sector in Malaysia. International Journal of Recent Technology and Engineering. Vol.8 (1):403-410.

4. Candido, Peres., \& Antao Mario. 2017. The use of multivariate discriminant analysis to predict corporate bankruptcy. International Journal Of Finance. Universidade Lusíada de Lisboa, Rua da Junqueira. Lisboa, Portugal. Vol (14): 108-131.

5. Carolina, Verani., Elyzabet I. Marpaung., \& Derry Pratama. 2017. Analisis Rasio Keuangan untuk Memprediksi Kondisi Financial Distress (Studi Empiris pada Perusahaan Manufaktur yang Terdaftar di Bursa Efek Indonesia Periode 2014-2015). Jurnal Akuntansi. Vol. 9(2):137-145.

6. Cherotich, Koech Emmy., Nyangaya Akuno., \& Mugo Robert. 2018. Prediction Of Financial Distress In The Light Of Financial Crisis: A Case Of Listed Firms In Kenya. International Journal Of Econmic, Commerce and Management, United Kingdom. Vol. 6(6): 207-226.

7. Darmawan, Arif., \& Joko Supriyanto. 2018. The Effect of Financial Ratio on Financial Distress in Predicting Bankruptcy. Journal Of Applied Managerial Accounting. Vol. 2(1): 110120.

8. Desiyanti, Ouw., Wahyoe Soedarmono., \& Kristian Chandra. 2019. The Effect of Financial Ratios to Financial Distress Using Altman Z-Score Method in Real Estate Companies Listed in Indonesia Stock Exchange Period 2014 - 2018. Journal of Business and Entrepreneurial. Vol.19(2):119-136.

9. Darmawan, Arif., \& Joko Supriyanto. 2018. The Effect of Financial Ratio on Financial Distress in Predicting Bankruptcy. Journal Of Applied
Managerial Accounting. Vol. 2(1):110120.

10. Fadrul \& Ridawati. 2020. Analysis of Method Used to Predict Financial Distress Potential in Pulp and Paper Companies of Indonesia. International Journal of Economics Development Research, Vol I(1): 57-69.

11. Fahmi, I. (2012). Analisis Kinerja Keuangan. Bandung: Alfabeta.

12. Finishtya, Florentina Cindy. 2019. The Role Of Cash Flow Of Operational, Profitability, And Financial Leverage In Predicting Financial Distress On Manufacturing Company In Indonesia. International Journal of Applied Management. Vol. 17 (1): 110-117.

13. Chalil, Diana., dan Rianti Barus, “ Analisis Data Kualitatif", USU Press, Medan,2014.

14. Ghozali, Imam. 2016. Aplikasi Analisis Multivariete Dengan. Semarang. Badan Penerbit Universitas Diponegoro.

15. Ghozali, Imam., \& Dwi Ratmono. 2019. Analisis Multivariat Dan Ekonometrika, Teori, Konsep, dan Aplikasi dengan Eviews 10. Semarang. Badan Penerbit Universitas Diponegoro.

16. Gusni., Sri Wiludjeng., \& Silviana. 2019. Predicting Financial Distress: A Case Study of Indonesia Coal Firms. Global Business and Management Research: An International Journal. Vol. 11( 1).

17. Hanafi, Imam., \& Stevanus Gatot Supriyadi. 2018. Prediksi Financial Distress Perusahaan manufaktur Yang Terdaftar Di Bursa Efek Indonesia. Jurnal Ekonomi Bisnis. Vol. 4 (1): 25-51.

18. Harahap, Sofyan Syafry. 2011.Analisis Kritis Atas Laporan Keuangan. Jakarta. Raja Grafindo Persada.

19. Hasan , Muhamad Faiz., \& Lilis Puspitawati. 2017. The Influence Liquidity Ratio And Leverage Ratio To Financial Distress. Journal of Economics and Business.

20. Hery. 2018. Analisis laporan keuangan. Jakarta. Penerbit Grasindo.

21. Hidayat, Muhammad Arif., \& Wahyu Meiranto. 2014. Prediksi Financial Distress Perusahaan Manufaktur Di 
Indonesia. Jurnal Akuntansi. Vol. 3 (3): 111.

22. Hillary, Osoro Kombo., Dr. Andrew Nyang'au., \& Prof. Christopher Ngacho. 2018. Effects of Financial Distress on Financial Performance of Manufacturing Firms Listed in Nairobi Securities Exchange. International Journals Of Academics \& Research. Vol. 1(1): 211220.

23. Hosaka, T. 2019. Bankruptcy prediction using imaged financial ratios and convolutional neural networks, Expert Systems with Application. Vol. 117: 287299.

24. Horvathova, Jarmila., \& Martina Mokrisova. 2018. Risk of Bankruptcy, Its Determinants and Models. Department of Accounting and Controlling, Faculty of Management, University of Presov, Konstantinova, Slovakia. Vol (6):1-22.

25. Indriaty, Novica., Doddy Setiawan., \& Yuwita Ariessa Pravasanti. 2019. The Effects Of Financial Ratio, Local Size And Local Status On Financial Distress. International Journal Of Economic, Business and Accounting Research.Vol 3(1):38-42.

26. Jabeur, S. 2017. Bankruptcy prediction using Partial Least Squares Logistic Regression. Journal of Retailing and Consumer Services. Vol.36: 197-202.

27. Jennings, Martha E. 2005. Applicability Of Altman's Revised Fpur Variabel ZScore As A Bankruptcy Predictor For Health Maintenance Organizations. Dissertation. Doctor Of Business Administration. Davie, Florida, Amerika Serikat. H. Wayne Huizenga School of Business and Entrepreneurship Nova Southeastern University.

28. Kamaluddin, Amrizah., Norhafizah Ishak., \& Nor Farizal Mohammed. 2019. Financial Distress Prediction Through Cash Flow Ratios Analysis. International Journal of Financial Research. Vol. 10(3): 63-76.

29. Karas, M., \& Reznakova. 2018. Building a bankruptcy prediction model: Could information about past development increase model accuracy. Polish Journal of
Management Studies. Vol. 17(1): 116130.

30. Kasmir. 2012 . Analisis Laporan Keuangan. Jakarta. Penerbit Rajawali Pers.

31. Kasmir. 2017. Analisis Laporan Keuangan. Jakarta. Penerbit Rajawali Pers.

32. Kim, Kyoung., Lee, Kichun., \& Ahn, Hyunchul. 2018. Predicting Corporate Financial Sustainability using Novel Business Analytics. Dongguk University Seoul. Sustainability. Vol. 11(64): 1-17.

33. Kliestik, Tomas., Jaromir Vrbka., \& Zuzana Rowland. 2018. Bankruptcy prediction in Visegrad group countries using multiple discriminant analysis. International Journal of Economics and Economic Policy. Institute of Technology and Business in Ceske Budejovice, Czech Republic. Vol 13(3): 569-593.

34. Lestari ,Setyani Dwi., Retno Fuji Oktaviani., \& Willy Arafah. 2016. Financial Distress Prediction With Altman Z-Score And Effect On Stock Price: Empirical Study On Companies Subsectors Chemical Listed In Indonesia Stock Exchange Period 2009-2014. International Journal of Business and Management Invention. Vol. 5 (8):30-39.

35. Li, L., \& Faff, R. 2019. Predicting corporate bankruptcy. International Review of Economics and Finance. Vol. 62: 1-19.

36. Matturungan, Nur Hasbullah., Budi Purwanto., \& Abdul Kohar Irwanto. 2017. Manufacturing Company Bankruptcy Prediction In Indonesia With Altman ZScore Model. Jurnal of Applied Management. Vol. 15 (1):18-24.

37. Masdupi, Erni., Abel Tasman., \& Atri Davista. 2018. The Influence of Liquidity, Leverage and Profitability on Financial Distress of Listed Manufacturing Companies in Indonesia. International Conference On Economics Education, Economics, Business and Management, Accounting and Entrepreneurship. Vol. 57 (1):223-228.

38. Muflihah, Intan Zakiyatul. 2017. Analisis Financial Distress Perusahaan Manufaktur 
Di Indonesia Dengan Regresi Logistik. Vol. 22(2):254-269.

39. Munawir, "Analisis Laporan Keuangan", Penerbit Liberty, Yogyakarta, 2010.

40. Nanayakkara K. G. M., \& A. A. Azeez. 2015. Predicting Corporate Financial Distress in Sri Lanka: An Extension to ZScore Model. International Journal of Business and Social Research. Vol. 05, No 03.

41. Nurfajrina, Annisa., Hermanto Siregar., \& Imam Teguh Saptono. 2016. Analisis Financial Distress Pada Perusahaan Agribisnis Di Bursa Efek Indonesia. Jurnal Keuangan dan Perbankan. Vol.20 (3): 448-457.

42. Nurhayati., Anna Mufidah., \& Asna Nur Kholidah. 2017. The Determinants of Financial Distress of Basic Industry and Chemical Companies Listed in Indonesia Stock Exchange. Journal Of Management And Entrepreneurship. Vol 1(2):19-26.

43. Pereira, Jose Manuel., Mario Basto., \& Amelia Ferreira da Silva. 2016. The logistic lasso and ridge regression in predicting corporate failure. Institute of Cavado and Ave, Portugal. Vol. 39: $634-$ 641.

44. Permana, Randy Kurnia., Nurmala Ahmar., \& Syahril Djaddang. 2017. Prediksi Financial Distress pada Perusahaan Manufaktur di Bursa Efek Indonesia. Jurnal Bisnis dan Manajemen. Vol. 7 (2): 149 - 166.

45. Prawirodipoero, Gema Muhammad., Raden Aswin Rahadi., \& Arif Hidayat.2019. The Influence of Financial Ratios Analysis on the Financial Performance of Micro Small Medium Enterprises in Indonesia. Review of Integrative Business and Economics Research, Vol. 8, No. 4.

46. Rafatnia, Ali Akbar., Suresh Ramakrishnan., \& Dewi Fariha. 2020. Financial Distress Prediction across Firms. Azman Hashim International Business School, UTM, Malaysia. Vol 8 (2): 646-651.

47. Restianti, Tya \& Linda Agustina. 2018. The Effect of Financial Ratios on Financial Distress Conditions in Sub
Industrial Sector Company. Accounting Analysis Journal. Vol.7(1): 25-33.

48. Sari, Warsani Purnama. 2020. The Effect of Financial Distress and Growth Opportunities on Accounting Conservatism with Litigation Risk as Moderated Variables in Manufacturing Companies Listed on BEI. Budapest International Research and Critics Institute Journa. Vol 3 (1):588-597.

49. Setyawati, Irma., \& Rizki Amalia. 2018. The Role of Current Ratio, Operating Cash Flow and Inflation Rate in Predicting Financial Distress: Indonesia Stock Exchange. Vol. 9 (2): 140-148

50. Shidiq, Jakaria Imam., \& Khairunnisa. 2019. Analisis Rasio Likuiditas, Rasio Leverage, Rasio Aktivitas, Dan Rasio Pertumbuhan Terhadap Financial Distress Menggunakan Metode Altman Z-Score Pada Sub Sektor Tekstil Dan Garmen Di Bei Periode 2013-2017. Jurnal Universitas Telkom Bandung. Vol. 7 (2):209-219.

51. Shilpa, N. C., \& M. Amulya. 2017. Corporate Financial Distress: Analysis of Indian Automobile Industry. Journal Management of University Mysore, Manasagangothri, Mysore, India. Vol. 8 (1): 47-54.

52. Sirait, Sarida. 2016. Analisis Rasio Keuangan Untuk Memprediksi Kondisi Financial Distress Pada Perusahaan Manufaktur Yang Terdaftar Di Bursa Efek Indonesia. Tesis. Magister Akuntansi Fakultas Ekonomi dan Bisnis Universitas Sumatera Utara.

53. Sulistyani., \& Deni Ismanto. 2017. Analisis Rasio Keuangan Untuk Memprediksi Kondisi Financial Distress Perusahaan Manufaktur Yang Terdaftar Di BEI. Jurnal Fokus. Vol. 7 (2): 156-157.

54. Sulistiyowati, Leny. 2016. Panduan Praktis Memahami Laporan Keuangan. Elex Media Komputindo.

55. Syamsuddin, Lukman. 2016. Manajemen Keuangan Perusahaan. Jakarta. Rajawali Pers.

56. Utami, Rezky., Hermanto Siregar., \& Ferry Syarifuddin. 2020. The Analysis of Bankruptcy Prediction Model with Adjustment of Earning Management on Textile and Garment Sub-Sector in 
Indonesia Stock Exchange. International Journal of Research and Review. IPB University, School of Business. Vol.7(1): 208-218.

57. Vo, Duc Hong., Binh Ninh Vo Pham., \& Michael McAleer. 2019. Corporate Financial Distress of Industry Level Listings in Vietnam. Journal Of Risk and Financial Management. Vol. 12.

58. Waqas, Hamid., \& Rohani Md-Rus. 2018. Predicting financial distress: Applicability of $\mathrm{O}$-score and logit mode for Pakistani firms. BEH- Business and Economic Horizons Vol. 14, No. 2.

59. Wijoyo, Nugroho Agung. 2016. Menakar Kinerja Perusahaan Pembiayaan: Kesulitan Keuangan Perusahaan Pembiayaan (Financial Distress). Jakarta. penerbit UI Press.

60. www.idx.co.id

61. www.ticmi.co.id
62. Yadiati, Winwin. 2017. The Influence Of Profitability On Financial Distress : A Research On Agricultural Companies Listed In Indonesia Stock Exchange. International Journal Of Scientific \& Technology Research.Vol. 6(11):233-237.

63. Yusbardini., \& Rosmita Rashid. 2019. Prediksi Financial Distress Dengan Pendekatan Altman Pada Perusahaan Manufaktur Di Indonesia. Jurnal Muara Ilmu Ekonomi dan Bisnis. Vol. 3 (1): 122129.

How to cite this article: Sibarani RY, Irawati N, Muda I. Analysis of financial ratio to predict financial distress in the sub sector of Plantation Company on Indonesia Stock Exchange Period 2010-2018. International Journal of Research and Review. 2021; 8(1): 36-47. 